\title{
Exciting perspectives for Translational Myology in the Abstracts of the 2018Spring PaduaMuscleDays: Giovanni Salviati Memorial - Chapter I - Foreword
}

\author{
Ugo Carraro $(1,2,3)$
}

(1) Laboratory of Translational Myology, Department of Biomedical Sciences, University of Padova; (2) A\&C M-C Foundation for Translational Myology, Padova; (3) IRCCS Fondazione Ospedale San Camillo, Venezia-Lido, Italy

This article is distributed under the terms of the Creative Commons Attribution Noncommercial License (CC BY-NC 4.0) which permits any noncommercial use, distribution, and reproduction in any medium, provided the original author(s) and source are credited.

\begin{abstract}
Myologists working in Padua (Italy) were able to continue a half-century tradition of studies of skeletal muscles, that started with a research on fever, specifically if and how skeletal muscle contribute to it by burning bacterial toxin. Beside main publications in high-impact-factor journals by Padua myologists, I hope to convince readers (and myself) of the relevance of the editing Basic and Applied Myology (BAM), retitled from 2010 European Journal of Translational Myology (EJTM), of the institution of the Interdepartmental Research Center of Myology of the University of Padova (CIR-Myo), and of a long series of International Conferences organized in Euganei Hills and Padova, that is, the PaduaMuscleDays. The 2018Spring PaduaMuscleDays (2018SpPMD), were held in Euganei Hills and Padua (Italy), in March 14-17, and were dedicated to Giovanni Salviati. The main event of the "Giovanni Salviati Memorial", was held in the Aula Guariento, Accademia Galileiana di Scienze, Lettere ed Arti of Padua to honor a beloved friend and excellent scientist 20 years after his premature passing. Using the words of Prof. Nicola Rizzuto, we all share his believe that Giovanni "will be remembered not only for his talent and originality as a biochemist, but also for his unassuming and humanistic personality, a rare quality in highly successful people like Giovanni. The best way to remember such a person is to gather pupils and colleagues, who shared with him the same scientific interests and ask them to discuss recent advances in their own fields, just as Giovanni have liked to do". Since Giovanni's friends sent many abstracts still influenced by their previous collaboration with him, all the Sessions of the 2018SpPMD reflect both to the research aims of Giovanni Salviati and the traditional topics of the PaduaMuscleDays, that is, basics and applications of physical, molecular and cellular strategies to maintain or recover functions of skeletal muscles. The translational researches summarized in the 2018SpPMD Abstracts are at the appropriate high level to attract approval of Ethical Committees, the interest of International Granting Agencies and approval for publication in top quality, international journals. This was true in the past, continues to be true in the present and will be true in the future. All 2018SpPMD Abstracts are indexed at the end of the Chapter IV.
\end{abstract}

Key Words: Giovanni Salviati, proof of concept, translational myology, PaduaMuscleDays Eur J Transl Myol 28 (1): 3-9, 2018

In a recent Commentary of Biology, Engineering, and Medicine (BEM), ${ }^{1}$ is described how Myologists working in Padua (Italy) were able to continue for half of century the tradition of studies on skeletal muscles, that started with a research project that had the aim to explain if and how skeletal muscle produces fever by burning bacterial toxins. Though the concept sounds very strange today, recent results on effects of myokines may reopen interest on it. ${ }^{2}$ Anyhow, beside publications in high impact factor journals by Padua scientists and clinicians, I hope to convince readers (and myself) of the relevance of the editing of Basic and Applied Myology (BAM), retitled from 2010 European Journal of Translational Myology (EJTM), of the institution of the Interdepartmental Research Center of Myology of the University of Padova 


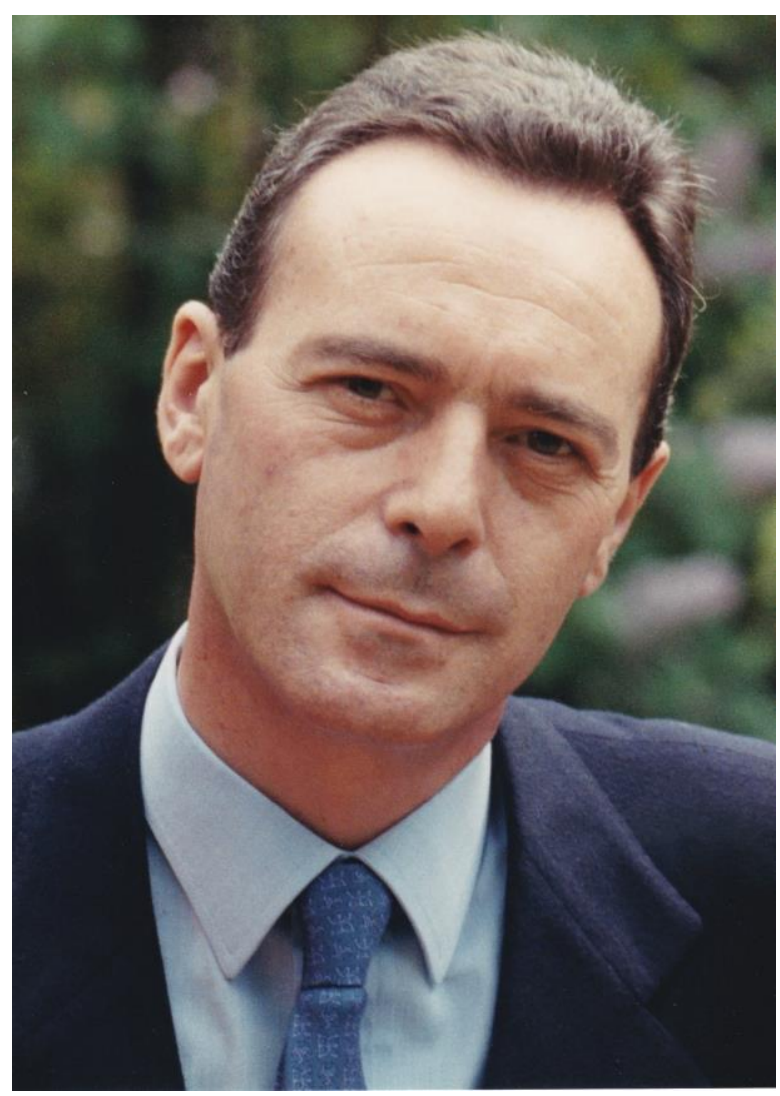

Fig 1. Giovanni Salviati

(CIR-Myo), and the PaduaMuscleDays (PMD), a series of International Conferences organized in Euganei Hills and Padova. I have some difficulties to reply to the eventual question of how many PMDs were held during the years since they were held irregularly twice a year, from their inception in 1984 with the First Abano Terme Meeting on Rehabilitation. The 2018Spring PaduaMuscleDays were held in Euganei Hills and Padua (Italy), March 14-18. The main event, the "Openings of the Giovanni Salviati Memorial", was held in the Aula Guariento, Accademia Galileiana di Scienze, Lettere ed Arti of Padua to honor a beloved friend and excellent scientist 20 years after his premature passing (Figures 1 and 2). We all share the sentiments of Prof. Nicolò Rizzuto that Giovanni Salviati will be remembered not only for his talent and originality as a biochemist, but also for his unassuming and humanistic personality, a rare quality in highly successful people like Giovanni. The best way to remember such a person is to gather pupils and colleagues, who shared with him the same scientific interests and ask them to discuss recent advances in their own fields, just as Giovanni have liked to do. This has not been a difficult task, because Giovanni, thanks to his widely recognized scientific knowledge and his unforgettable personality, had been in close touch with many basic and clinical scientists around the world. Established scientists found in Giovanni a valued collaborator, rich in knowledge, expertise, and humanity, while younger scientists were introduced to research in the rigorous but pleasant atmosphere of Giovanni's lab. Presentations summarize recent results in the field of muscle physiopathology by basic and clinical scientists. Many of them are members of, or have collaborated with, two prestigious institutions in which Giovanni worked: the Department of Biomedical Sciences (formerly Institute of General Pathology) at the University of Padova, and the Department of Neurology at Columbia University. The former, since the pioneering years under the leadership of the late Professor Massimiliano Aloisi, is recognized worldwide as a center of excellence for research in muscle physiopathology. The latter is not only one of the best centers for the study of neuromuscular diseases, but also an invaluable resource for Italian science. In the Clinical Research Center directed by Salvatore Di Mauro, many young Italian scientists have been trained in the past 50 years, and many have returned to Italy, where they have established highly competitive research groups.$^{3}$ Many of them accepted invitation and sent proposals for presentations still influenced by their previous collaboration with him. ${ }^{4-70}$ All the Sessions of the 2018SpPMD were thus inspired to the research aims and results of Giovanni Salviati as they developed during recent years (Figure 2). As was in the past PMDs, ${ }^{71-97}$ the abstracts of 2018 are on physical, pharmacological and cellular strategies to maintain or recover functions of skeletal muscles. They are at the very high level needed to attract support by International Granting Agencies and approval by Ethical Committees. Many of the abstracts demonstrate indeed that their results are mature to be translated to clinical applications. This was true in the past, ${ }^{96,97}$ it will be hopefully true in the future.

\section{Acknowledgments and Funding}

This typescript is sponsored by the A\&C M-C Foundation for Translational Myology, Padova, Italy.

\section{Conflict of Interest}

The author declare to have none conflicts of interests.

\section{Ethical Publication Statement}

Authors confirm that they have read the Journal's position on issues involved in ethical publication and affirm that this report is consistent with those guidelines.

\section{Corresponding Authors}

Ugo Carraro, Laboratory of Translational Myology, Department of Biomedical Sciences, University of Padova, Italy. E-mail: ugo.carraro@unipd.it

\section{References}

1. Carraro U. From BAM to BEM, a personal journey through EJTM and PaduaMuscleDays. Biol Eng Med 2017; 2(2): 1-2 doi: 10.15761/BEM.1000117.

2. Gabellini D, Musarò A. Report and Abstracts of the 14th Meeting of IIM, the Interuniversity Institute of 
Myology, - Assisi (Italy), October 12-15, 2017. Eur J Transl Myol 2017;27:185-224.

3. Rizzuto $N$. Introduction. Italian $J$ Neurol Sci 1990;20:365.

4. Irwin W, Fontaine E, Agnolucci L, Penzo D, Betto $R$, Bortolotto $S$, Reggiani $C$, Salviati G, Bernardi P. Bupivacaine myotoxicity is mediated by mitochondria. J Biol Chem 2002;277:12221-7. Epub 2002 Jan 14..

5. Betto R, Senter L, Ceoldo S, Tarricone E, Biral D, Salviati G. Ecto-ATPase activity of alphasarcoglycan (adhalin). J Biol Chem 1999;274:7907-12.

6. Presotto $C$, Agnolucci L, Biral D, Dainese $P$, Bernardi P, Salviati G. A novel muscle protein located inside the terminal cisternae of the sarcoplasmic reticulum. J Biol Chem 1997;272:6534-8.

7. Betto $R$, Teresi A, Turcato F, Salviati $G$, Sabbadini $R A$, Krown $K$, Glembotski CC, Kindman LA, Dettbarn C, Pereon Y, Yasui K, Palade PT. Sphingosylphosphocholine modulates the ryanodine receptor/calcium-release channel of cardiac sarcoplasmic reticulum membranes. Biochem J 1997;322 (Pt 1):327-33.

8. Schiaffino S, Salviati G. Molecular diversity of myofibrillar proteins: isoforms analysis at the protein and mRNA level. Methods Cell Biol 1997;52:349-69. Review.

9. Li X, Hughes SM, Salviati G, Teresi A, Larsson L. Thyroid hormone effects on contractility and myosin composition of soleus muscle and single fibres from young and old rats. J Physiol 1996;494 (Pt 2):555-67.

10. Danieli-Betto D, Betto R, Megighian A, Midrio M, Salviati $G$, Larsson $L$. Effects of age on sarcoplasmic reticulum properties and histochemical composition of fast-and slow-twitch rat muscles. Acta Physiol Scand 1995;154:59-64.

11. Dettbarn $C$, Betto $R$, Salviati $G$, Sabbadini $R$, Palade $P$. Involvement of ryanodine receptors in sphingosylphosphorylcholine-induced calcium release from brain microsomes. Brain Res 1995;669:79-85.

12. Senter L, Ceoldo S, Petrusa MM, Salviati G. Phosphorylation of dystrophin: effects on actin binding. Biochem Biophys Res Commun 1995;206:57-63.

13. McDonough PM, Yasui K, Betto R, Salviati $G$, Glembotski CC, Palade PT, Sabbadini RA. Control of cardiac Ca2+ levels. Inhibitory actions of sphingosine on Ca2+ transients and L-type Ca2+ channel conductance. Circ Res 1994;75:981-9.

14. Larsson L, Li X, Teresi A, Salviati G. Effects of thyroid hormone on fast- and slow-twitch skeletal muscles in young and old rats. J Physiol. 1994;481 (Pt 1):149-61..
15. Bertini E, Salviati G, Apollo F, Ricci E, Servidei $S$, Broccolini A, Papacci M, Tonali P. Reducing body myopathy and desmin storage in skeletal muscle: morphological and biochemical findings. Acta Neuropathol 1994;87:106-12.

16. Salvatori S, Furlan S, Millikin B, Sabbadini R, Betto $R$, Margreth A, Salviati G. Localization of protein kinase $C$ in skeletal muscle T-tubule membranes. Biochem Biophys Res Commun 1993;196:1073-80..

17. Luciani GB, D'Agnolo A, Mazzucco A, Gallucci V, Salviati G. Effects of ischemia on sarcoplasmic reticulum and contractile myofilament activity in human myocardium. Am J Physiol 1993;265(Pt 2):H1334-41.

18. Luise M, Presotto C, Senter L, Betto R, Ceoldo $S$, Furlan S, Salvatori S, Sabbadini RA, Salviati G. Dystrophin is phosphorylated by endogenous protein kinases. Biochem J 1993;293 (Pt 1):243-7.

19. Sabbadini R, McNutt W, Jenkins $G$, Betto R, Salviati $G$. Sphingosine is endogenous to cardiac and skeletal muscle. Biochem Biophys Res Commun. 1993;193(2):752-8.

20. Senter L, Luise M, Presotto C, Betto R, Teresi A, Ceoldo $S$, Salviati G. Interaction of dystrophin with cytoskeletal proteins: binding to talin and actin. Biochem Biophys Res Commun 1993;192:899-904.

21. Larsson L, Salviati G. A technique for studies of the contractile apparatus in single human muscle fibre segments obtained by percutaneous biopsy. Acta Physiol Scand 1992;146:485-95.

22. Sabbadini RA, Betto R, Teresi A, Fachechi-Cassano $G$, Salviati G.The effects of sphingosine on sarcoplasmic reticulum membrane calcium release. J Biol Chem 1992;267:15475-84.

23. Cavazzana AO, Schmidt D, Ninfo $V$, Harms $D$, Tollot M, Carli M, Treuner J, Betto R, Salviati G. Spindle cell rhabdomyosarcoma. A prognostically favorable variant of rhabdomyosarcoma. Am J Surg Pathol. 1992 Mar;16(3):229-35.

24. D'Agnolo A, Luciani GB, Mazzucco A, Gallucci V, Salviati G. Contractile properties and $\mathrm{Ca} 2+$ release activity of the sarcoplasmic reticulum in dilated cardiomyopathy. Circulation. 1992;85:518-25.

25. Betto R, Teresi A, Fachechi-Cassano G, Salviati G, Sabbadini RA. Sphingosine inhibits calcium release from sarcoplasmic reticulum membranes. Adv Exp Med Biol 1992;311:403-4.

26. Bertini E, Bosman C, Ricci E, Servidei S, Boldrini $R$, Sabatelli $M$, Salviati $G$. Neuromyopathy and restrictive cardiomyopathy with accumulation of intermediate filaments: a clinical, morphological and biochemical study. Acta Neuropathol 1991;81:632-40.

27. Klitgaard H, Zhou M, Schiaffino S, Betto R, Salviati $G$, Saltin B. Ageing alters the myosin heavy chain composition of single fibres from human skeletal muscle. Acta Physiol Scand. 1990 Sep;140(1):5562. 
28. Salviati G, Betto R, Ceoldo S, Pierobon-Bormioli $S$. Morphological and functional characterization of the endosarcomeric elastic filament. Am J Physiol 1990;259(1 Pt 1):C144-9.

29. Klitgaard H, Bergman $O$, Betto $R$, Salviati $G$, Schiaffino S, Clausen T, Saltin B. Co-existence of myosin heavy chain I and IIa isoforms in human skeletal muscle fibres with endurance training. Pflugers Arch 1990;416:470-2.

30. Salvatori S, Damiani E, Barhanin J, Furlan S, Salviati G, Margreth A. Co-localization of the dihydropyridine receptor and the cyclic AMPbinding subunit of an intrinsic protein kinase to the junctional membrane of the transverse tubules of skeletal muscle. Biochem J 1990;267:679-87.

31. Larsson L, Salviati G. Effects of age on calcium transport activity of sarcoplasmic reticulum in fastand slow-twitch rat muscle fibres. J Physiol 1989;419:253-64.

32. Pierobon-Bormioli $S$, Betto $R$, Salviati $G$. The organization of titin (connectin) and nebulin in the sarcomeres: an immunocytolocalization study. J Muscle Res Cell Motil 1989;10:446-56.

33. Salviati G, Betto R, Ceoldo S, Tegazzin V, Della Puppa A. Caffeine sensitivity of sarcoplasmic reticulum of fast and slow fibers from normal and malignant hyperthermia human muscle. Muscle Nerve 1989;12:365-70.

34. Salviati $G$, Betto R, Ceoldo S, Biasia E, Bonilla E, Miranda AF, Dimauro $S$. Cell fractionation studies indicate that dystrophin is a protein of surface membranes of skeletal muscle. Biochem J 1989;258:837-41.

35. Miranda AF, Francke $U$, Bonilla E, Martucci $G$, Schmidt B, Salviati G, Rubin M. Dystrophin immunocytochemistry in muscle culture: detection of a carrier of Duchenne muscular dystrophy. Am J Med Genet 1989;32:268-73.

36. Salvatori $S$, Damiani E, Zorzato $F$, Volpe $P$, Pierobon S, Quaglino D Jr, Salviati G, Margreth A. Denervation-induced proliferative changes of triads in rabbit skeletal muscle. Muscle Nerve 1988;11:1246-59.

37. Bonilla E, Miranda AF, Prelle A, Salviati G, Betto $R$, Zeviani M, Schon EA, DiMauro S, Rowland LP. Immunocytochemical study of nebulin in Duchenne muscular dystrophy. Neurology 1988;38:1600-3.

38. Bonilla E, Samitt CE, Miranda AF, Hays AP, Salviati G, DiMauro S, Kunkel LM, Hoffman EP, Rowland LP. Duchenne muscular dystrophy: deficiency of dystrophin at the muscle cell surface. Cell 1988;54:447-52.

39. Zeviani M, Darras BT, Rizzuto R, Salviati G, Betto $R$, Bonilla E, Miranda AF, Du J, Samitt C, Dickson $G$, et al. Cloning and expression of human nebulin cDNAs and assignment of the gene to chromosome 2q31-q32. Genomics. 1988;2:249-56.
40. Salviati $G$, Volpe $P$. Ca2+ release from sarcoplasmic reticulum of skinned fast- and slowtwitch muscle fibers. Am J Physiol 1988;254(3 Pt 1):C459-65.

41. Biral D, Betto R, Danieli-Betto D, Salviati G. Myosin heavy chain composition of single fibres from normal human muscle. Biochem $J$ 1988;250:307-8.

42. Volpe P, Zorzato F, Pozzan T, Salviati G, Di Virgilio F. Measurement of calcium release from sarcoplasmic reticulum of skeletal muscle: effect of calcium and inositol 1,4,5-trisphosphate. Methods Enzymol 1987;141:3-18.

43. Salviati G, Biasia E, Aloisi M. Synthesis of fast myosin induced by fast ectopic innervation of rat soleus muscle is restricted to the ectopic endplate region. Nature. 1986;322(6080):637-9.

44. Salviati $G$, Betto $R$, Danieli-Betto D, Biasia E, Serena M, Mini M, Scarlato G. Myosin light chains and muscle pathology. Neurology 1986;36:693-7.

45. Volpe P, Di Virgilio F, Pozzan T, Salviati G. Role of inositol 1,4,5-trisphosphate in excitationcontraction coupling in skeletal muscle. FEBS Lett 1986;197:1-4. Review.

46. Salviati G, Biasia E, Betto R, Danieli Betto D. Fast to slow transition induced by experimental myotonia in rat EDL muscle. Pflugers Arch 1986;406:266-72.

47. Di Virgilio F, Salviati G, Pozzan T, Volpe P. Is a guanine nucleotide-binding protein involved in excitation-contraction coupling in skeletal muscle? EMBO J 1986;5:259-62.

48. Volpe P, Salviati G, Chu A. Calcium-gated calcium channels in sarcoplasmic reticulum of rabbit skinned skeletal muscle fibers. J Gen Physiol 1986;87:289-303. Review.

49. Volpe P, Salviati G, Di Virgilio F, Pozzan $T$. Inositol 1,4,5-trisphosphate induces calcium release from sarcoplasmic reticulum of skeletal muscle. Nature. 1985;316(6026):347-9.

50. Zorzato F, Salviati G, Facchinetti T, Volpe P. Doxorubicin induces calcium release from terminal cisternae of skeletal muscle. A study on isolated sarcoplasmic reticulum and chemically skinned fibers. J Biol Chem 1985;260:7349-55.

51. Salviati $G$, Zeviani $M$, Betto $R$, Nacamulli $D$, Busnardo B. Effects of thyroid hormones on the biochemical specialization of human muscle fibers. Muscle Nerve 1985;8:363-71.

52. Salviati $G$, Pierobon-Bormioli $S$, Betto R, Damiani E, Angelini C, Ringel SP, Salvatori S, Margreth A. Tubular aggregates: sarcoplasmic reticulum origin, calcium storage ability, and functional implications. Muscle Nerve 1985;8:299-306.

53. Pierobon-Bormioli S, Armani M, Ringel SP, Angelini C, Vergani L, Betto R, Salviati G. Familial neuromuscular disease with tubular aggregates. Muscle Nerve 1985;8:291-8. 
54. Salviati G, Betto R, Danieli Betto D, Zeviani M. Myofibrillar-protein isoforms and sarcoplasmicreticulum Ca2+-transport activity of single human muscle fibres. Biochem J 1984;224:215-25.

55. Salviati G, Betto R, Danieli Betto D. Polymorphism of myofibrillar proteins of rabbit skeletal-muscle fibres. An electrophoretic study of single fibres. Biochem J 1982;207:261-72.

56. Biral D, Damiani E, Volpe P, Salviati G, Margreth A. Polymorphism of myosin light chains. An electrophoretic and immunological study of rabbit skeletal-muscle myosins. Biochem J 1982;203:52940.

57. Salviati G, Sorenson MM, Eastwood AB. Calcium accumulation by the sarcoplasmic reticulum in two populations of chemically skinned human muscle fibers. Effects of calcium and cyclic AMP. J Gen Physiol 1982;79:603-32.

58. Salviati $G$, Salvatori $S$, Betto $R$, Margreth A. Molecular and antigenic properties of cytochrome b5 from slow-muscle sarcoplasmic reticulum. Biochem J 1981;197:515-8.

59. Damiani E, Betto R, Salvatori S, Volpe P, Salviati $G$, Margreth A. Polymorphism of sarcoplasmicreticulum adenosine triphos-phatase of rabbit skeletal muscle. Biochem J 1981;197:245-8.

60. Margreth A, Dalla Libera L, Salviati G, Ischia N. Spinal transection and the postnatal differentiation of slow myosin isoenzymes. Muscle Nerve. 1980;3:483-6.

61. Salviati $G$, Betto $R$, Salvatori $S$, Margreth $A$. Evidence for the presence of the stearyl-CoA desaturase system in the sarcoplasmic reticulum of rabbit slow muscle. Biochim Biophys Acta 1979;574:280-9.

62. Margreth A, Carraro U, Salviati G. Structural membrane proteins and loosely associated proteins of the sarcoplasmic reticulum. Biochem J 1974;139:509-13.

63. Margreth A, Salviati G, Carraro U. Neural control on the activity of the calcium-transport system in sarcoplasmic reticulum of rat skeletal muscle. Nature 1973;241(5387):285-6.

64. Margreth A, Salviati G, Di Mauro S, Turati G. Early biochemical consequences of denervation in fast and slow skeletal muscles and their relationship to neural control over muscle differentiation. Biochem J 1972;126:1099-110.

65. Mussini I, Margreth A, Salviati G. On the criteria for characterization of calcium oxalate in sarcoplasmic reticulum fragments. J Ultrastruct Res 1972;38:459-65.

66. Margreth A, Salviati G. Biochemical characteristics of slow skeletal muscle in workinduced hypertrophy. Biochem J 1971;124:669-71.

67. Margreth A, Salviati G, Catani C. Electron transport in sarcoplasmic reticulum of fast and slow muscles. Arch Biochem Biophys 1971;144:768-72.
68. Margreth A, Di Mauro S, Tartarini A, Salviati G. Glycogen synthetase in developing and adult skeletal muscle. Biochem J 1971;122:597-9.

69. Margreth A, Angelini $C$, Valfrè $C$, Salviati $G$. Developmental patterns of $\mathrm{LDH}$ isozymes in fast and slow muscles of the rat. Arch Biochem Biophys 1970;141:374-7.

70. Editors. Abstracts of the 2017Spring PaduaMuscleDays, March 23-25, Montegrotto and Padua (Italy). Eur J Transl Myol 2017;27:81-112.

71. Editors. Muscle Decline in Aging and Neuromuscular Disorders - Mechanisms and Countermeasures: Terme Euganee, Padova (Italy), April 13-16, 2016. Eur J Transl Myol 2016;26:5904. doi: 10.4081/ejtm.2016.5904. eCollection 2016 Feb 23.

72. Editors. Functional Rejuvenation in Aging and Neuromuscular Disorders. Eur J Transl Myol 2015;25:269-75. doi: 10.4081/ejtm.2015.5607 eCollection 2015 Aug 24.

73. Editors. 2015Spring PaduaMuscleDays, March 1214, 2015 - Terme Euganee (Padova), Italy Abstracts Eur J Transl Myol 2015;25:145-82.

74. Power GA, Dalton BH, Gilmore KJ, et al. Maintaining Motor Units into Old Age: Running the Final Common Pathway. Eur J Transl Myol 2017;27:6597. doi: 10.4081/ejtm.2017.6597. eCollection 2017 Feb 24.

75. Coletti D, Adamo S, Moresi V. Of Faeces and Sweat. How Much a Mouse is Willing to Run: Having a Hard Time Measuring Spontaneous Physical Activity in Different Mouse Sub-Strains. Eur J Transl Myol 2017;27:6483. doi: 10.4081/ejtm.2017.6483. eCollection 2017 Feb 24.

76. Pigna E, Greco E, Morozzi G, et al. Denervation does not Induce Muscle Atrophy Through Oxidative Stress. Eur J Transl Myol 2017;27:6406. doi: 10.4081/ejtm.2017.6406. eCollection 2017 Feb 24.

77. Coste CA, Mayr W, Bijak M, et al. FES in Europe and Beyond: Current Translational Research. Eur J Transl Myol. 2016;26:6369. doi: 10.4081/ejtm.2016.6369. eCollection 2016 Sep 15.

78. Scicchitano BM, Sica G, Musarò A.Stem Cells and Tissue Niche: Two Faces of the Same Coin of Muscle Regeneration. Eur J Transl Myol 201;26:6125. doi: 10.4081/ejtm.2016.6125. eCollection 2016 Sep 15.

79. Lavorato M, Gupta PK, Hopkins PM, FranziniArmstrong C. Skeletal Muscle Microalterations in Patients Carrying Malignant HyperthermiaRelated Mutations of the e-c Coupling Machinery. Eur J Transl Myol 2016;26:6105. doi: 10.4081/ejtm. 2016.6105. eCollection 2016 Sep 15.

80. Carotenuto F, Coletti D, Di Nardo P, Teodori. L $\alpha$ Linolenic Acid Reduces TNF-Induced Apoptosis in C2C12 Myoblasts by Regulating Expression of Apoptotic Proteins. Eur J Transl Myol 


\section{SpPMD: Giovanni Salviati Memorial, March 15-17}

Eur J Transl Myol 28 (1): 3-9, 2018

2016;26:6033. doi: 10.4081/ejtm. 2016.6033. eCollection 2016 Sep 15.

81. Mosole S, Carraro U, Kern H, et al. Use it or Lose it: Tonic Activity of Slow Motoneurons Promotes Their Survival and Preferentially Increases Slow Fiber-Type Groupings in Muscles of Old Lifelong Recreational Sportsmen. Eur J Transl Myol 2016;26:5972. doi: 10.4081/ ejtm.2016.5972. eCollection 2016 Sep 15.

82. Edmunds KJ, Gíslason MK, Arnadottir ID, et al. Quantitative Computed Tomography and Image Analysis for Advanced Muscle Assessment. Eur J Transl Myol 2016;26:6015. doi: 10.4081/ejtm. 2016.6015. eCollection 2016 Jun 13.

83. Coletti D, Daou N, Hassani M, et al. Serum Response Factor in Muscle Tissues: From Development to Ageing. Eur J Transl Myol 2016;26:6008. doi: 10.4081/ejtm.2016. 6008. eCollection 2016 Jun 13.

84. Hiroux C, Vandoorne T, Koppo et al. Physical Activity Counteracts Tumor Cell Growth in Colon Carcinoma C26-Injected Muscles: An Interim Report. Eur J Transl Myol 2016;26:5958. doi: 10.4081/ejtm.2016.5958. eCollection 2016 Jun 13.

85. Tramonti C, Rossi B, Chisari C. Extensive Functional Evaluations to Monitor Aerobic Training in Becker Muscular Dystrophy: A Case Report. Eur J Transl Myol 2016;26:5873. doi: 10.4081/ejtm.2016.5873. eCollection 2016 Jun 13.

86. Riuzzi F, Beccafico S, Sorci G, Donato R. S100B protein in skeletal muscle regeneration: regulation of myoblast and macrophage functions. Eur J Transl Myol 2016;26:5830. doi: 10.4081/ejtm.2016.5830. eCollection 2016 Feb 23.

87. Barber L, Scicchitano BM, Musaro A. Molecular and Cellular Mechanisms of Muscle Aging and Sarcopenia and Effects of Electrical Stimulation in Seniors. Eur J Transl Myol 2015;25:231-6. doi: 10.4081/ejtm.2015.5227. eCollection 2015 Aug 24. Review.

88. Gabrielli E, Fulle S, Fanò-Illic G, Pietrangelo T. Analysis of Training Load and Competition During the PhD Course of a 3000-m Steeplechase Female Master Athlete: An Autobiography. Eur J Transl Myol 2015;25:5184. doi: 10.4081/ejtm.2015.5184. eCollection 2015 Sep 11.

89. Gargiulo P, Helgason T, Ramon C, et al. CT and MRI Assessment and Characterization Using Segmentation and 3D Modeling Techniques: Applications to Muscle, Bone and Brain. Eur J Transl Myol 2014;24:3298. doi: 10.4081/ejtm. 2014 3298. eCollection 2014 Mar 31.
90. Ortolan P, Zanato $R$, Coran A, et al. Role of Radiologic Imaging in Genetic and Acquired Neuromuscular Disorders. Eur J Transl Myol 2015;25:5014. doi: 10.4081/ejtm.2015.5014. eCollection 2015 Mar 11. Review.

91. Ravara B, Gobbo V, Carraro U, et al. Functional Electrical Stimulation as a Safe and Effective Treatment for Equine Epaxial Muscle Spasms: Clinical Evaluations and Histochemical Morphometry of Mitochondria in Muscle Biopsies. Eur J Transl Myol 201525:4910. doi: 10.4081/ejtm.2015.4910. eCollection 2015 Mar 11.

92. Franzini-Armstrong C. Electron Microscopy: From $2 D$ to $3 D$ Images with Special Reference to Muscle. Eur J Transl Myol 2015;25:4836. doi: 10.4081/ejtm.2015.4836. eCollection 2015 Jan 7. Review.

93. Costa A, Rossi E, Scicchitano BM, et al. Neurohypophyseal Hormones: Novel Actors of Striated Muscle Development and Homeostasis. Eur J Transl Myol 2014;24:3790. doi: 10.4081/ejtm.2014.3790. eCollection 2014 Sep 23. Review.

94. Veneziani S, Doria C, Falciati L, Castelli CC, Illic GF. Return to Competition in a Chronic Low Back Pain Runner: Beyond a Therapeutic Exercise Approach, a Case Report. Eur J Transl Myol 2014;24:2221. doi: 10.4081/ejtm.2014. 2221. eCollection 2014 Sep 23.

95. Azevedo-Coste $C$, Vergeron $V$, Berkelmans $R$, et al. Comparison of strategies and performance of functional electrical stimulation cycling in spinal cord injury pilots for competition in the first ever CYBATHLON. Eur J Transl Myol 2017;27:251-4.

96. Kern H, Hofer C, Löfler S, et al. Atrophy, ultrastructural disorders, severe atrophy and degeneration of denervated human muscle in SCI and Aging. Implications for their recovery by Functional Electrical Stimulation, updated 2017. Neurol Res 2017;39:660-666. doi: 10.1080/01616412.2017.1314906. Epub 2017 Apr 13.

97. Kern H, Carraro U, Adami N, et al. Home-based functional electrical stimulation rescues permanently denervated muscles in paraplegic patients with complete lower motor neuron lesion. Neurorehabil Neural Repair 2010; 24:709-21.

Received for publication: February 20, 2018 Accepted for publication: February 21, 2018 